\title{
The 3D printing in industrial design
}

\author{
Druk 3D we wzornictwie przemysłowym
}

\section{STANISŁAW ADAMCZAK} MARCIN GRABA*
DOI: https://doi.org/10.17814/mechanik.2020.1.1
Industrial design is an interdisciplinary activity leading to the development of new products that can be successfully launched on the market. Generally, the term industrial design is understood as the design process leading to the determination of various features of the industrial form. For many years, design was practiced using standard techniques such as sketch, presentation drawing, technical drawing, and mockups. However, the development of additive manufacturing techniques meant that an indispensable element in the industrial design is 3D printing, which allows to quickly create a prototype, a model of the designed detail. In this paper, on the example of engineering studies in the field of industrial design, the use of 3D printing in the process of design will be shown.

KEYWORDS: industrial design, design, 3D printing, additive manufacturing, teaching

Wzornictwo przemysłowe to interdyscyplinarna działalność prowadząca do opracowania nowych produktów, które z powodzeniem można wprowadzić na rynek. Na ogół pod pojęciem wzornictwa przemysłowego rozumie się proces projektowania prowadzący do określenia różnych cech formy przemysłowej. Przez wiele lat projektowanie wzornicze uprawiane było z wykorzystaniem standardowych technik typu szkic, rysunek prezentacyjny, rysunek techniczny i makieta. Jednakże rozwój addytywnych technik wytwarzania sprawił, że nieodzownym elementem w projektowaniu stał się druk 3D, który pozwala szybko stworzyć prototyp, makietę, projektowany detal. W niniejszej pracy, na przykładzie inżynierskich studiów z zakresu wzornictwa przemysłowego, pokazano wykorzystanie druku 3D w procesie projektowania wzorniczego.

SŁOWA KLUCZOWE: wzornictwo przemysłowe, projektowanie, druk 3D, techniki przyrostowe, nauczanie

\section{Introduction}

Presenting and launching a new product to a group of consumers is a fairly long and bumpy road, starting with ideas, sometimes written and drawn on scraps of paper, and ending with the successful launch of the product on the market by obtaining a prize or a grandprix at a world exhibition in field in which the product was developed. Most people do not realize how the process of creating a new product is extensive. When deciding to introduce a new product, the company must examine the market in detail, determine the appropriate design assumptions for it, and specify to which group of recipients it will refer. In addition, such a product by definition must be functional, aesthetic, ergonomic, as well as arousing desire among the society, which is a condition for its good sale. In addition, it is necessary to make it from the right materials, ensuring a certain strength and if there is a need for mechanical work, and the structure itself must be faultless. The whole is to be an industrial form that will encourage potential customers to buy this product. Analyzing all these aspects, one can come to the conclusion that when introducing a new product to the market, you need to know the aspects of technical sciences in the field of mechanics or strength of materials, broadly understood material science, construction, design, giving proper aesthetics, as well as ergonomics or the basics of economics, so that everything is profitable.

Of course, it can be said that understanding of all this requires study - one by one in various fields. However, according to the old saying "it is the mother of inventions" to properly educate a designer to work in the design of new industrial forms, an interdisciplinary field of science was created - a direction of education, which was called industrial design. Polish traditions of industrial design go quite deep, starting from the end of the $19^{\text {th }}$ century, where Polish applied art developed, through the excellent achievements of the interwar period (as shown at the International Exhibition of Decorative Arts and Design in Paris in 1925), the development of the Institute of Industrial Design after World War II, up to modern times, when many great designers achieve successes in creating new products not only in the domestic but also on the international arena. For many years in the field of industrial design, studies were conducted by selected faculties of the academies of fine arts or art schools. It was only in the $21^{\text {st }}$ century that the need to link design works in the field of visual arts with engineering aspects began to be recognized. It turned out that the science of giving the right aesthetics to new products - an industrial form cannot exist without technique. This resulted in the opening of engineering studies in the field of industrial design at the Cracow University of Technology, the Koszalin University of Technology and in 2014 at the Kielce University of Technology (KUT), at the Faculty of Mechatronics and Mechanical Engineering.

\footnotetext{
* Prof. dr hab. inż. Stanisław Adamczak dr h.c. (multi), adamczak@tu.kielce.pl, https://orcid.org/0000-0002-7797-6330 - Faculty of Mechatronics and Mechanical Engineering, Kielce University of Technology, Kielce, Poland 


\section{Industrial design - definitions, dependencies}

Quoting in [1], according to Thomas Maldonado of the International Council of Societies of Industrial Design (ICSID): industrial design is a creative activity whose purpose is to determine the formal values of items produced by industry. These formal values include the external features of products, but above all those structural and functional relationships that transform the product as a system into a coherent whole from the point of view of the manufacturer and the buyer. Industrial design makes it necessary to cover all aspects of the human environment conditioned by and directed at industrial production.

In 1986, at the Institute of Industrial Design in Warsaw, Andrzej Przedpełski defined industrial design as a method of operation making an idea of an object that can be produced and from which, thanks to its visual attractiveness and functional qualities, it is possible to make goods, that is to sell [1]. Therefore, thanks to the widely understood design, the profits from introducing a new industrial form to the market belong to both the originator - investor, designer, production plant, and the final recipient - the client, enjoying new, sometimes innovative product.

In 1999, Professor Wojciech Wybieralski, defined design in the aspect of his profession, stating that: design, and especially industrial design can be understood and cultivated as a professional activity of a design nature - interdisciplinary, but the most conditional functional and functional, technical and economic issues, and focused on giving form to products. It can be called product form engineering [1]. In 2009, Professor Wybieralski discussed the place and role of industrial design in product development quite broadly, concluding the work with the definition of a pentagon of industrial design, pointing to the interdisciplinary nature of this field - professional activity [2].

To sum up, industrial design in all specializations is a very specific field that combines such distant professions related to technology, economics, material culture, art, fashion, ergonomics, ecology and sociology [1]. Although the design of industrial design is closely related to art, it should be noted that it is a rational activity, always based on the right methods of operation [2] - criteria, design assumptions, aesthetic or construction assumptions.

\section{Industrial design science, 3D printing implementation}

Established in 2014, the youngest field of study at Faculty of Mechatronics and Mechanical Engineering at Kielce University of Technology, under the name industrial design, offers its students 3.5-year first degree studies, ending with the title of professional engineer, in two specialties - industrial forms design and design engineering industrial. Emphasizing modern production technologies, automated production processes, extending to broadly understood prototyping of many program content by introducing as many hours as possible to classes with students in the field of rapid prototyping - fast production, taking into account in as many items as possible the use of 3D printing technology.

Students in the field of industrial design at KUT, realizing a wide study program, gain basic knowledge from various fields in the field of technology and art. They learn methods, techniques and tools for designing, manufacturing and control. In addition, they become acquainted with the methods of designing a given product or product group, while maintaining all visual, functional and market values. The study program implemented by students guarantees knowledge of many computer programs and systems that support the stages of design, production and analysis (calculation programs, 2D and 3D CAD constructing programs, graphics processing and processing programs, etc.).

A graduate of industrial design at KUT is qualified to use widely understood CAD/CAM/CAE systems to create new industrial designs, using rapid prototyping technologies, combining with 3D printing. In carrying out various teaching activities, students use the possibilities of 3D printing to varying degrees, which allows quickly on the basis of a virtual 3D model to create a tangible effect of the work of a designer engineer, in the form of a prototype that can be a single detail or a complex product, which will be shown in the next chapter of this paper.

Thanks to the acquired skills, a graduate of industrial design is able to create and implement his own design concepts, can work in a team or independently develop the designer skills using literature and media in both Polish and a foreign languages. Thanks to a whole range of practical classes (projects, laboratories, exercises), it is possible for graduates of industrial design to use various computer systems while assisting in design, manufacture, engineering calculations or the presentation of completed design concepts. Interdisciplinarity in the field of education is also guaranteed by graduates in the field of industrial design in accordance with the assumptions of technical documentation, taking into account ergonomics, product aesthetics and economic conditions.

All these aspects of the work of an engineer - an in-dustrial design designer - are included in the design work from the first classes in the field of industrial forms design to the final thesis. The basis for design in industrial design is the product synthesis scheme given by Eskild Tjalve [3], which, according to the author of this paper, can be used not only to develop a new industrial form, but also after some changes to develop other projects in the field of industrial design.

The product synthesis scheme that appears during the subsequent practical classes fits perfectly into the design process of the new industrial form. Among the seven main stages of this scheme, there are three main ones that perfectly describe the work of an industrial design designer:

- artistic works, among which we can distinguish conceptual drawings, artistic drawings, sketches;

- engineering works, among which are the basic design and construction of both 2D and 3D; analytical 
strength calculations and calculations using the finite element method;

- 3D modeling, prototyping and 3D prototype printing.

The third stage, where we can distinguish 3D printing, gives a tangible effect of the engineer's work. Many people outside the industry are wondering what $3 \mathrm{D}$ printing really is. The term 3D printing should be understood as the process of producing three-dimensional, physical objects based on a computer model, prepared in appropriate engineering or graphic software. For many years, 3D printing was the only method of rapid prototyping that was used to build new industrial forms as well as to create prototypes. However, technological progress in the development of manufacturing methods allows achieving more and more accurate production of objects using 3D printers, which is why 3D printing is currently the basis for additive techniques for producing finished products in the form of toys, clothes, small mechanical parts, prostheses or even check.

As mentioned above, 3D printing is a stage - a component of rapid prototyping. In general, 3D printing is the culmination of the work of an engineer - industrial design designer, who transferred his thoughts and concept sketches to the proper CAD computer program, where he visualized the model of a new industrial form. The use of CAD methods for visualization is used in virtually all sectors of the industry (medicine, dentistry, machine industry, automotive industry, electronics, general manufacturing industry, architecture, interior design, etc.). However, the CAD model of the new industrial form is still a virtual model, which with the use of 3D printing technology can be transferred from this virtual reality to the real world.

The 3D printing is a component of rapid prototyping technology. This term should be understood as the total set of various techniques that are used to create objects based on models prepared in 3D CAD programs. Generally, the developed CAD model is saved in the program used for design in the form of a *.stl file, which is a special file format created by 3D Systems for the needs of spatial printing, referred to in literature as stereolithography. These files are a set of text commands, usually executed in a loop, defining the polygon mesh. Then the *.stl file is generally used in the software provided with the $3 \mathrm{D}$ printer to generate a G-code, which is a set of commands for the 3D printer.

The model in the technology of rapid prototyping with the use of 3D printing is created based on the additive technique - simplifying, it should be said that the model is created by joining successive thin layers of the created object. These layers are laid from various materials (plastics, gypsum powder, building powders sintered by laser, metal powders, metallic powders or sand powders bonded with a liquid binder). Additive manufacturing technology has some advantage over traditional manufacturing techniques. It allows to create models with shapes that are difficult to implement using, for example, machining.

Many papers were devoted to discussing the divisions of $3 \mathrm{D}$ printing, pros and cons of this technology.
It should be noted that this is a fairly expensive technique for producing new industrial designs. However, at present, due to the developing technological progress, this method cannot be omitted in the design of new industrial forms. In the next section of this paper, selected projects carried out by students of industrial design at KUT will be shown, in the implementation of which the three stages of design work listed above, including the use of 3D printing, were used to develop a prototype or model of the designed form industry.

\section{Selected engineer diploma thesis carried out by KUT's students in the field of industrial design using 3D printing technology}

One of the many projects carried out as part of engineering diploma thesis was the proposal of new vessels for drinking liquids. In this thesis [4], Eng. Natalia Kowalska, developed two projects that were also protected by the Patent Office of the Republic of Poland in the field of industrial design - a herb/tea/coffee brewing mug and a "non-spill" mug for young children. In addition to a number of conceptual works in the form of sketches, the completed thesis gives development of 3D models, tips for developing the G-code required for the preparation of prototypes, which were printed on plaster 3D printers, strengthening the external surfaces with a special glue (Fig. 1). a)

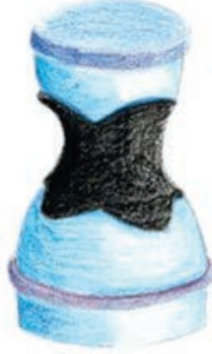

b)

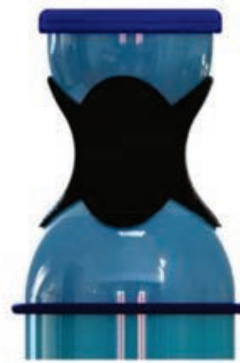

c)

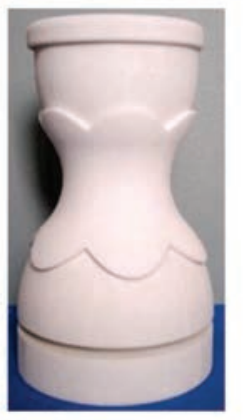

d)

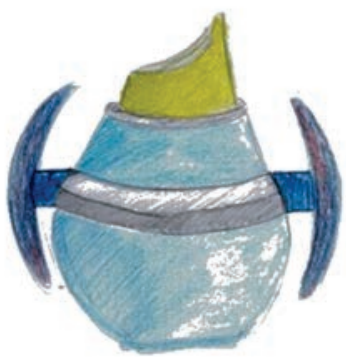

e)

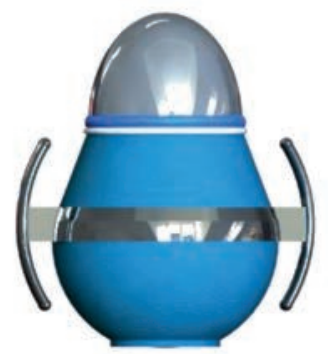

f)

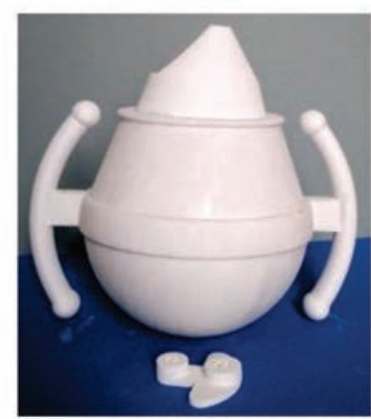

Fig. 1. Concept sketches $(a, d)$, 3D models $(b, e)$ and prototypes printed from plaster on a 3D printer $(c, f)$ developed and implemented as part of the engineer diploma thesis by Natalia Kowalska [4] 
Another thesis, combining typical design methods in the form of sketches, 3D modeling and 3D printing, was also carried out at the turn of 2018-2019 by Eng. Oliwia Władyszewska and concerned the development of a new form of a bus stop [5]. In addition to a number of design works, including sketches, developed 3D models or visualization, the culmination of the work is a mock-up developed by the graduate student using 3D printing technology (Fig. 2) [5]. An innovative element of the proposed form of the bus stop is the possibility of supplying it with energy obtained from piezoelectric panels installed at the stopping place before the bus stop [5].

Another type of engineer diploma thesis is a project proposed by Eng. Monika Szlompek [6], where, in addition to conceptual work, 3D modeling, the structure was optimized to reduce weight and recommendations for 3D printing of the developed industrial form were given to present the prototype (Fig. 3) [6].

Martyna Kmiecik has also used the 3D printing to develop the possibility of developing the selected space in the city park [7]. Using the variation of main elements, through a series of sketches, the author of the diploma thesis [7] proposed to develop a specific spa-
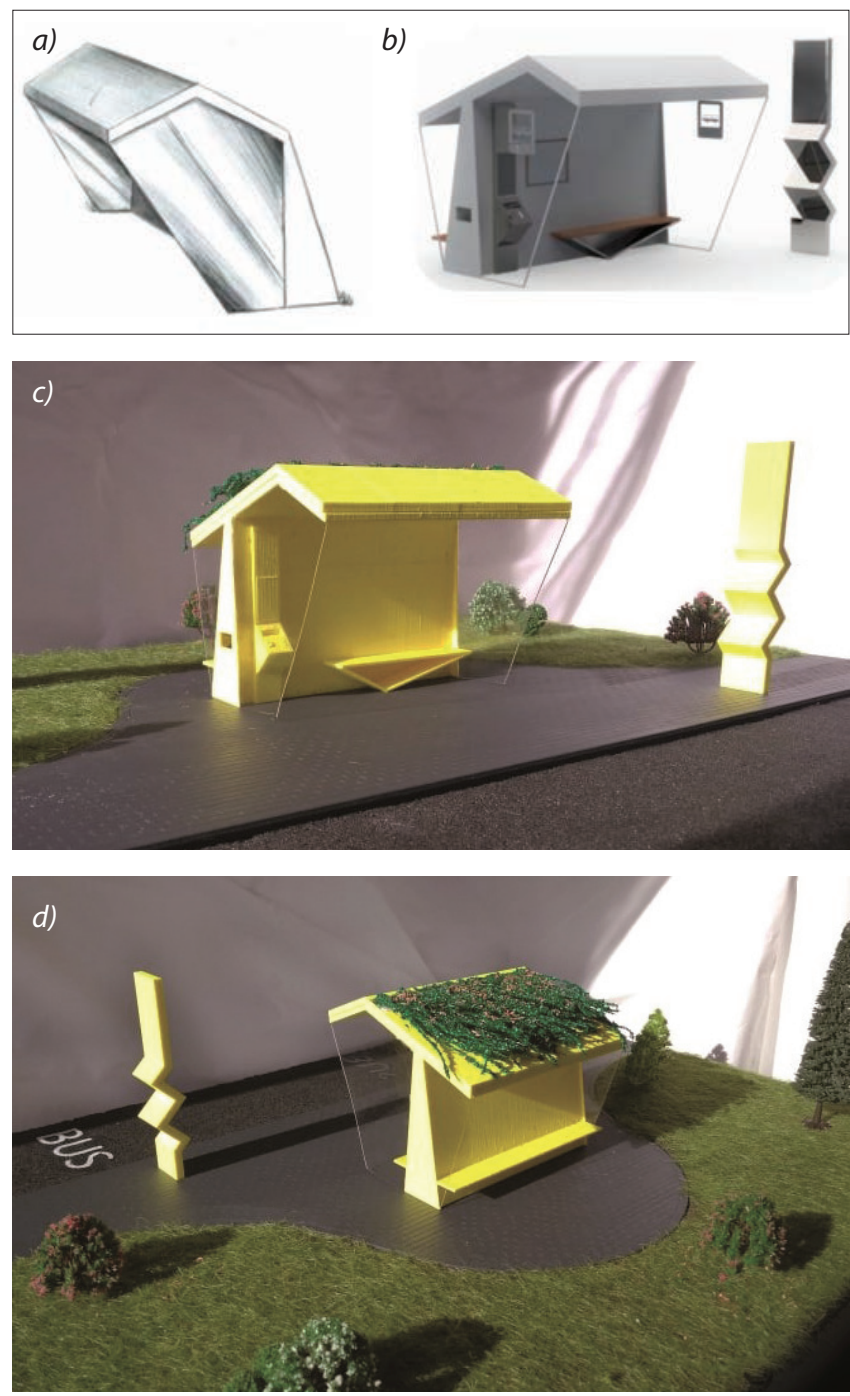

Fig. 2. A conceptual sketch (a), 3D model $(b)$ and a prototype of a new form of a bus stop printed on a 3D printer and presented in the form of a mockup $(c, d)$, developed and implemented as part of the engineer diploma thesis by Oliwia Władyszewska [5] ce in the Staszic Park in Kielce, on the basis of which she developed a detailed 3D model, using three different modeling programs. The resulting 3D models, depending on the software, were used to determine the limit load capacity or accurate visualization. The culmination of the developed thesis is a fairly detailed model, developed using 3D printing, because only such technology guaranteed its quick and accurate preparation [7] (Fig. 4).

Another example of using 3D printing to develop a prototype is the diploma thesis of Eng. Sandra Jędrych, who proposed a new form of the designer desk, in which the slide-out keyboard shelf used when working with a computer, thanks to the use of a fairly
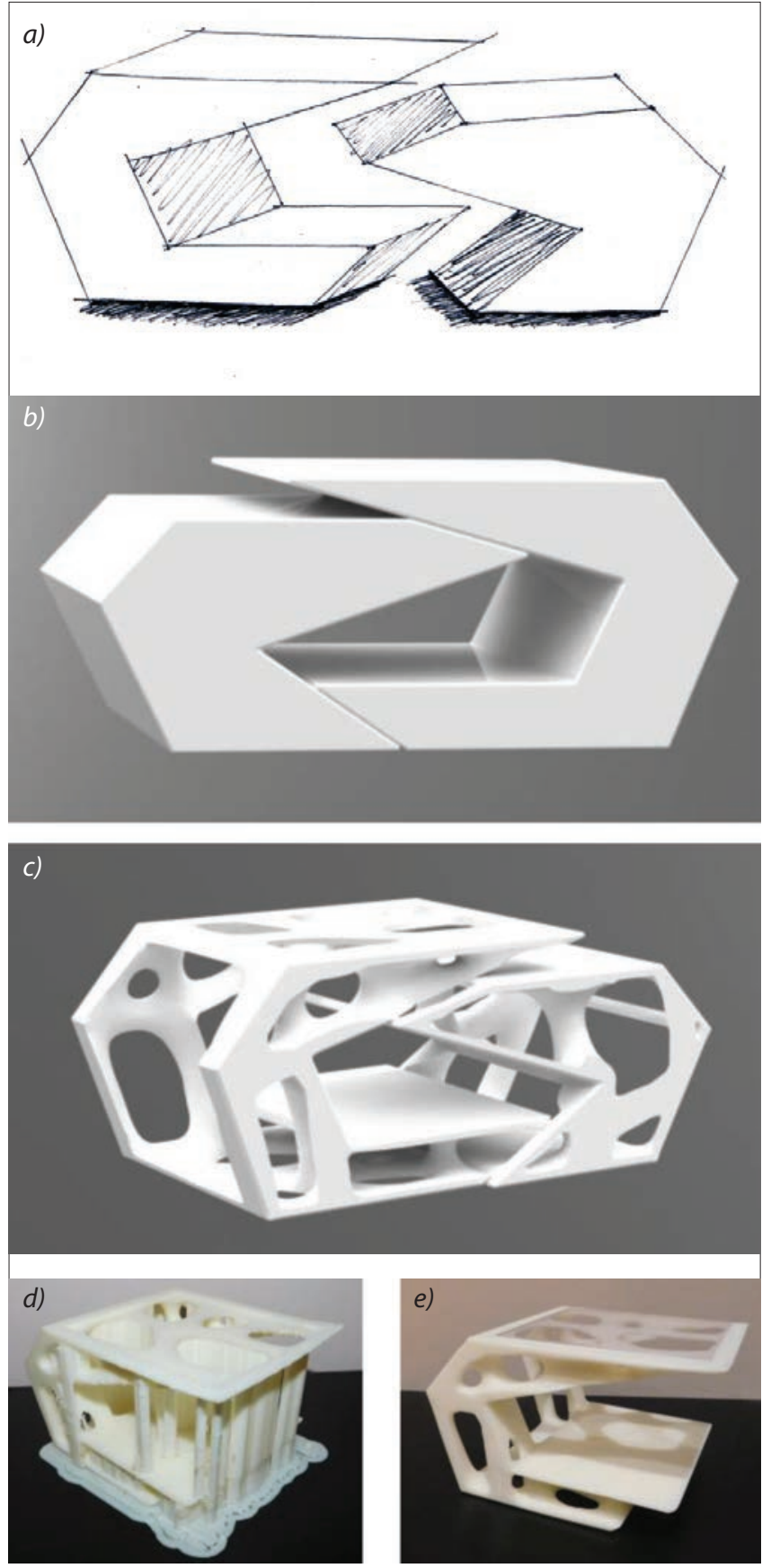

Fig. 3. Concept sketch (a), 3D model before optimization $(b)$ and after optimization (c), and a prototype of one part of the new form of a coffee table printed on a 3D printer - model after removal from the $3 \mathrm{D}$ printer and before removing supports $(d), 3 \mathrm{D}$ print-out after cleaning and removal of supports $(e)$ - the project carried out by Monika Szlompek as a diploma thesis [6] 

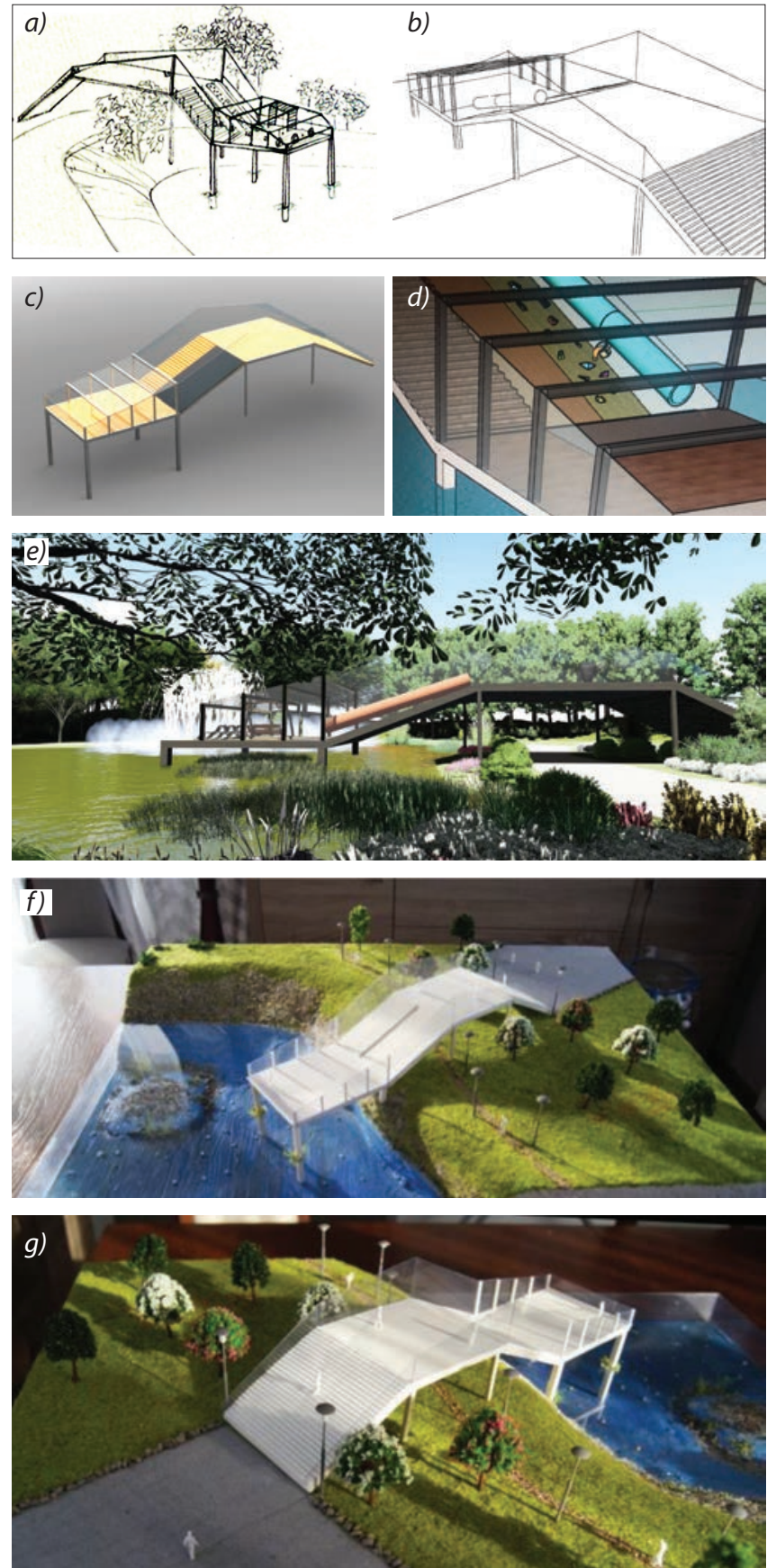

Fig. 4. Engineering project prepared by Martyna Kmiecik [7] - space management in a city park: $a-b$ ) conceptual sketches; $c-d$ ) 3D models made for the needs of the project; $e$ ) project visualization; $f-g$ ) model mockup built on the basis of elements made using 3D printing technology [7]

simple, but intelligent solution, becomes a drawing board, and decorative furniture additions can be connected without welds and will be used as a monitor shelf [8] (Fig. 5). The technical solutions and visual aspect used in the project resulted in the industrial form developed in the diploma thesis [8] being covered by Patent Office of the Republic of Poland protection in the field of industrial design.

The 3D printing was also used in the implementation of many other diploma theses. Among them you can find very practical designs, such as the 3D printer casing (Fig. 6); a new smartphone cover (Fig. 7) with miniature solar panels provided to make it easier to charge the phone when using it outdoors on sun-
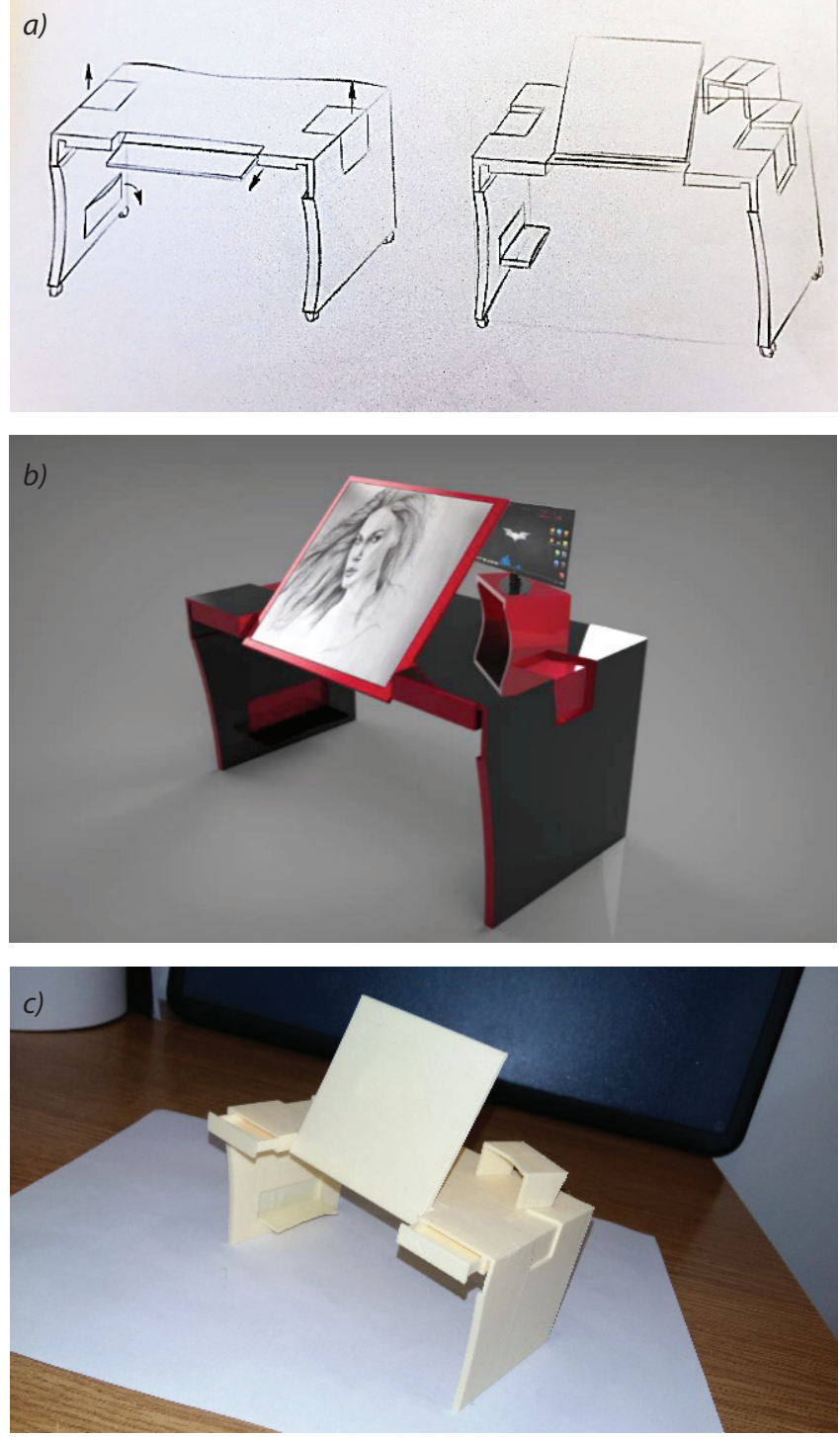

Fig. 5. Engineering project prepared by Eng. Sandra Jędrych [8] a design for a multifunctional desk: $a$ ) conceptual sketches; $b$ ) 3D model; $c$ ) a desk prototype made using 3D printing technology [8]

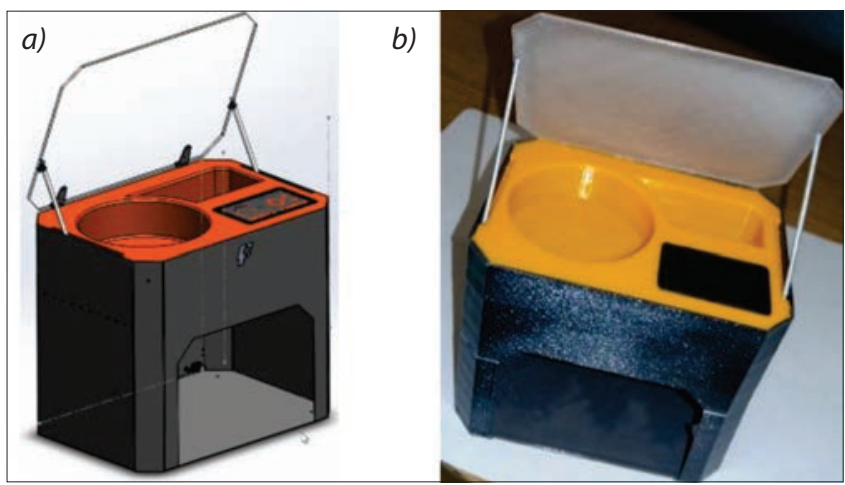

Fig. 6. Konrad Szmit's engineering project [9] - design of the casing for a modern 3D printer: a) 3D model developed in SOLID WORKS; b) a prototype of the printer casing made using 3D printing technology [9]

ny days; multifunctional modern piece of furniture (Fig. 8), which can be a mini desk or coffee table.

The use of 3D printing in furniture prototyping also allows you to assess the stability of the structure, determine its behavior under the influence of load, evaluate the area of the restricted area, which allows for safe use of the furniture (Fig. 9). Another area of use 

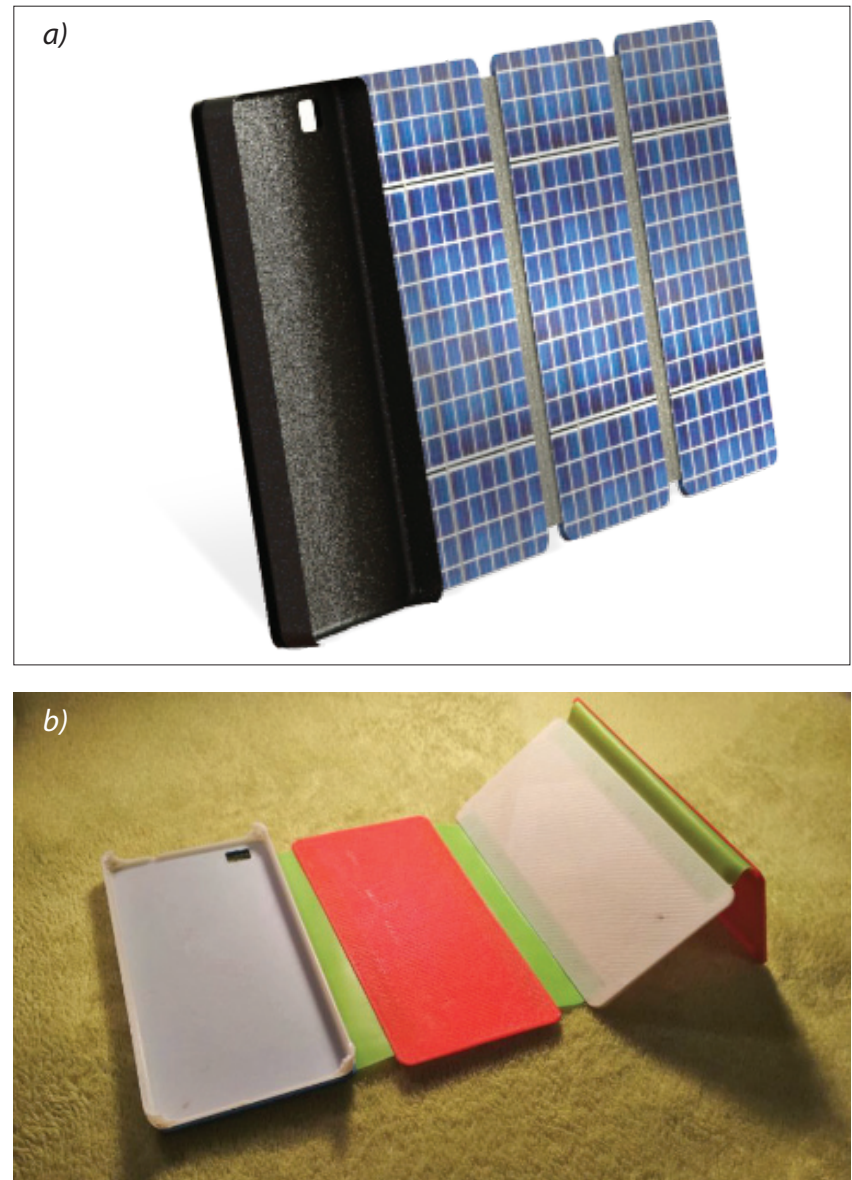

Fig. 7. An engineering project prepared by Anna Stanek [10] - a new smartphone cover, powered by solar batteries: a) 3D model after rendering; $b$ ) a housing prototype made using 3D printing technology [10]

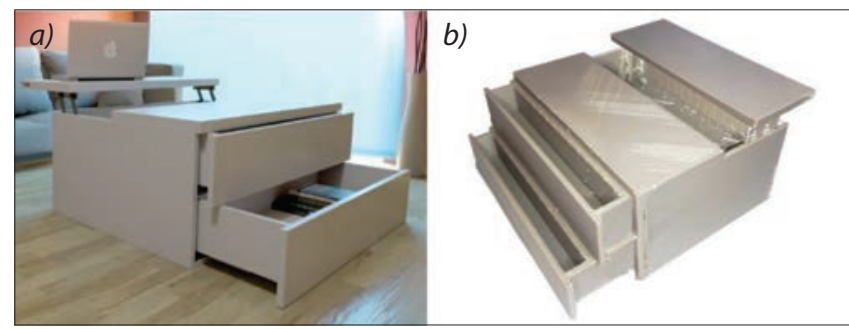

Fig. 8. Engineering project presented by Ewelina Pokrzywińska [11] - a modern multi-functional piece of furniture: a) 3D model made in SOLID WORKS - furniture visualization; $b$ ) a piece of furniture prototype made using 3D printing technology [11]

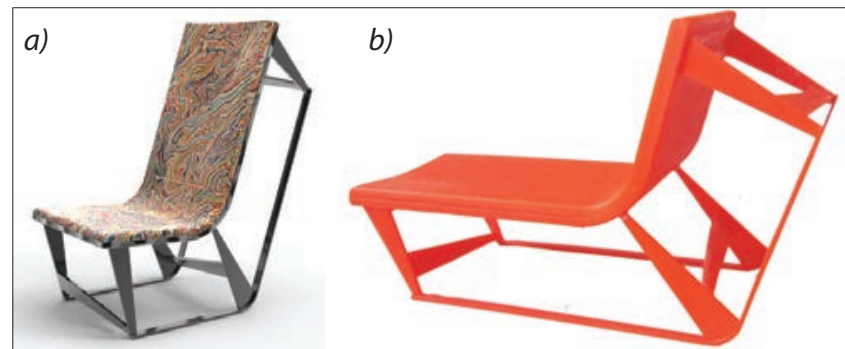

Fig. 9. Engineering project prepared by Natalia Dzmira [12] - a modern piece of furniture: $a$ ) 3D model; $b$ ) a prototype made by 3D printing technology [12]

of 3D printing is jewelry design (Fig. 10). A prototype made by $3 \mathrm{D}$ printing can be helpful in assessing the structure before proper production, or it can be used to create an injection mold or casting mold.

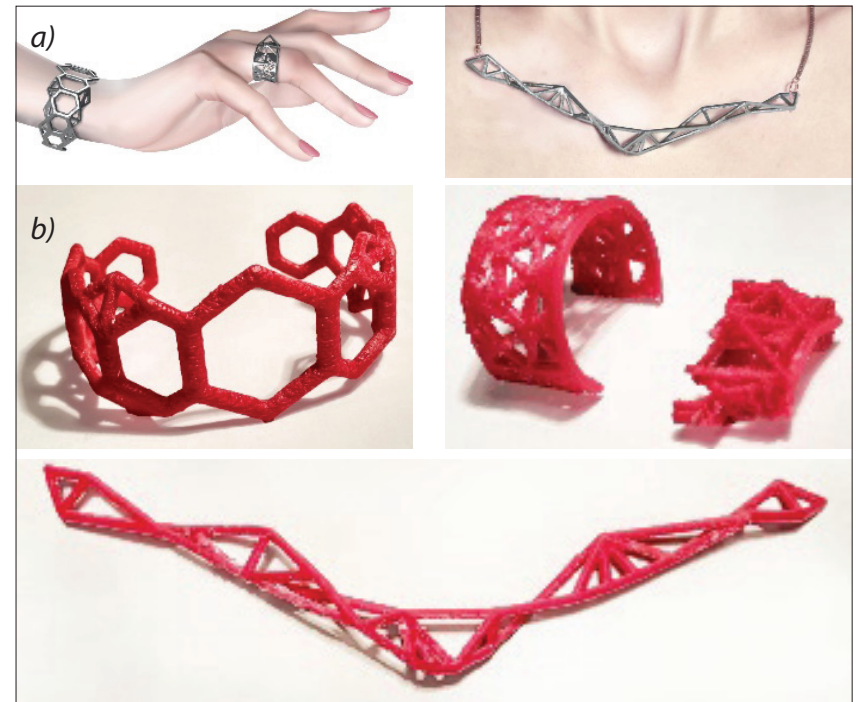

Fig. 10. Engineering project presented by Małgorzata Biłejszys [13] application of 3D printing in jewelry production: a) 3D models after rendering; $b$ ) prototypes made using 3D printing technology [13]

\section{Summary}

Currently, design is not only sketches, selection of materials, but also 3D modeling and 3D printing, which use in the creation of prototypes is an indispensable element of the work of an industrial design engineer. The use of 3D printing in the science of industrial design, makes classes and diploma theses more attractive and can be the basis for determining the right production technology in mass production, or restricted areas defined in the design of new industrial forms [3].

\section{REFERENCES}

[1] Balcerzak P., Wybieralski W., Stefanowski M. „O wzornictwie przemysłowym (definicje, procedury, korzyści)”. Warszawa: ASP w Warszawie, 2007.

[2] Wybieralski W. „Miejsce i rola wzornictwa przemysłowego w powstawaniu produktu". Mechanik. 82, 11 (2009): 945-948.

[3] Tjalve E. "A Short Course in Industrial Design". Newnes Butter worths, 1979.

[4] Kowalska N. „Projekt koncepcyjny wielofunkcyjnego naczynia do spożywania płynów". Praca dyplomowa WMiBM. Kielce: PŚk, 2019.

[5] Władyszewska 0. „Nowoczesna forma przystanku autobusowego z innowacyjnymi źródłami energii”. Praca dyplomowa WMiBM. Kielce: PŚk, 2019.

[6] Szlompek M. „Projekt koncepcyjny zestawu nowoczesnych mebli z wykorzystaniem metod szybkiego prototypownia". Praca dyplomowa WMiBM. Kielce: PŚk, 2019.

[7] Kmiecik M. „Wstepny projekt wzorniczy dla zagospodarowania wybranej przestrzeni w parku miejskim". Praca dyplomowa WMiBM. Kielce: PŚk, 2019.

[8] Jędrych S. „Wstępny projekt wzorniczy wielofunkcyjnego mebla do salonu/sypialni". Praca dyplomowa WMiBM. Kielce: PŚk, 2019.

[9] Szmit K. „Projekt obudowy nowoczesnej drukarki 3D”. Praca dyplomowa WMiBM. Kielce: PŚk, 2018.

[10] Stanek A. „Projekt wykorzystania energii słonecznej do zasilania urzq̨dzeń mobilnych". Praca dyplomowa WMiBM. Kielce: PŚk, 2018.

[11] Pokrzywińska E. „Projekt nowoczesnego mebla wielofunkcyjnego". Praca dyplomowa WMiBM. Kielce: PŚk, 2018.

[12] Dzimira N. „Projekt nowoczesnego mebla wypoczynkowego". Praca dyplomowa WMiBM. Kielce: PŚk, 2018.

[13] Biłejszys M. „Wykorzystanie drukarek 3D w projektowaniu galanterii biżuteryjnej". Praca dyplomowa WMiBM. Kielce: PŚk, 2018. 